\title{
Educational Involvement in Innovative University-Industry Collaboration
}

\author{
Leena Kunttu
}

\author{
"Even if the relationship between us and our university" \\ partner has been primarily a research collaboration \\ serving our $R \& D$, the educational dimension of this \\ collaboration has also been very important in \\ developing us new skills and competences in new \\ fields. Thus, by involving with educational activities, \\ we have enabled efficient knowledge transfer from the \\ academic world to our own $R \& D$.
}

Technology Manager

Case company D

\begin{abstract}
The positive link between university research and industrial innovation has been widely recognized among academics and industrial practitioners. A remarkable volume of previous research emphasizes the importance of the transfer of academic knowledge into the industrial domain. In this sense, it is surprising that the role of university education is an almost neglected topic in the research concerning university-industry collaboration, despite education and the creation of knowledge being a primary goal of universities and providing great potential in terms of improving competences. This study presents a case study that analyzes educational involvement in nine long-term university-industry relationships. In all the cases, the research collaboration between industrial firm and university research group is directly associated with close educational involvement. The aim of the case analysis is to understand mechanisms and practices of educational collaboration that facilitate relational learning and innovation development in university-industry relationships. The forms of educational involvement studied in this article include student projects, thesis projects, jointly organized courses, and tailored degree courses. The findings of the study reveal a number of educational collaboration practices that may facilitate relational learning, creation of new knowledge, as well as innovation development in university-industry relationships.
\end{abstract}

\section{Introduction}

Previous research has shown that innovative research collaboration between universities and industrial firms may effectively facilitate shared knowledge creation, learning, and joint innovation and, therefore, it acts as a stimulator of economic growth (Laursen \& Salter, 2004; Weckowska, 2015). University-industry relationships typically involve collaborative research, contract research, educational collaboration, personnel mobility, or contracting (D'Este \& Patel, 2007; Perkmann et al., 2013). Whereas the importance of the transfer of academic knowledge into the industrial domain has been highlighted in previous research (e.g., Ankrah \& Al-Tabbaa, 2015; Perkmann et al., 2013), educational collaboration taking place as a part of university-industry research collaborations is an almost neglected topic. This is surprising, because education and the creation of knowledge is a primary goal of universities, and involvement in academic educational activities is a source of great potential in terms of improving the competences of firms seeking new skills and competences (Santoro \& Chakrabarti, 1999) or wishing to develop their own internal capabilities. Indeed, previous studies on university-industry relationships mention education, training, and student projects as potential academic opportunities for industrial actors participating in university-industry relationships, for facilitators of a deepening academic engagement between the parties (Arvanitis et al., 2008; Bruneel et al., 2010; Perkmann et 


\section{Educational Involvement in Innovative University-Industry Collaboration}

\section{Leena Kunttu}

al., 2013), and for contributors to the creation of joint knowledge (Weckowska, 2015). However, prior understanding of how educational activities contribute the creation of joint knowledge and learning in university-industry relationships is very limited.

Educational collaboration can be defined as interactions between academic institutions and non-academic organizations involving academic educational activities. Thus, educational collaboration in university-industry relationships may consist of joint educational activities, training, or different kinds of student projects (Arvanitis et al., 2008; Bruneel et al., 2010; Maietta, 2015; Perkmann et al., 2013), all taking place in the relationships between academia and industry. To understand the facilitating practices of educational collaboration in university-industry relationships, this article uses the theory of relational joint learning (Kuwada, 1998; Selnes \& Sallis, 2003) as a theoretical framework. The relational learning approach has so far received relatively little research interest in the context of university-industry relationships (Weckowska, 2015), despite scholars showing that the learning process that takes place in collaborative relationships is an essential enabler of joint innovation involving knowledge creation, transfer, interpretation, and utilization (Bäck \& Kohtamäki, 2016; Selnes \& Sallis, 2003). Moreover, the innovativeness of firms participating in university-industry relationships has been shown to be dependent on how successful they are at acquiring and developing knowledge through learning in these collaborative relationships (Bruneel et al., 2010; Laursen \& Salter, 2004). This study intends to answer the following research question: How can educational collaboration facilitate relational learning and knowledge creation in university-industry relationships? To address this question, this article presents nine case examples of successful educational involvement in longterm university-industry research collaboration.

\section{Relational Learning in University-Industry Relationships}

The learning process taking place in relationships between industry and universities has been recognized as an essential facilitator of the transfer and integration of new, external knowledge in firms. This relational learning process also helps partners to jointly build new internal capabilities for innovation and to identify ways of joint knowledge development and utilization towards commercial ends (Weckowska, 2015). In this study, the relational learning approach is applied to the collaboration taking place in university-industry relationships. Selnes and Sallis (2003) define relational learning as a joint activity between two parties, in which they share information, which is then jointly interpreted and integrated into a shared relationship domain-specific memory. Thus, the relational learning process consist of three interconnected phases in which the research partners "1) share knowledge, 2) jointly make sense of it, and 3) integrate that knowledge into relational memory" (Selnes \& Sallis, 2003). In the first phase, knowledge sharing, the partners share and transfer information and knowledge in formal and informal manners within their relationship. In the context of university-industry relationships, the process of knowledge transfer from academia to industry has been studied by several teams of researchers (e.g., Ankrah et al., 2013; D'Este \& Patel, 2007; Siegel et al., 2004). Typical forms of knowledge transfer include jointly organized research projects, training and education, consulting engagements, or thesis supervision. The transfer of technological knowledge is an important part of the relational learning process, because innovative collaboration involves close sharing of experience-based specialized knowledge that is often tacit in nature. In the second phase, joint sensemaking, the partners work together to achieve a mutual understanding, create new knowledge, and solve practical problems in their common development work (Selnes \& Sallis, 2003). Thus, the joint sensemaking combines the resources, competences. and previous knowledge of the partners to jointly develop new knowledge that is typically relationship specific and thus difficult to utilize outside the partnership. The third phase, knowledge integration, refers to the integration of the jointly developed knowledge, capabilities, and skills into a part of the relational memory owned by the partners. In university-industry collaboration, the partners often integrate the outcomes of their joint development processes as commercialized innovations, prototypes, or academic outcomes (Perkmann et al., 2013).

\section{Case Study on Educational Involvement in University-Industry Relationships}

To explore the involvement of industrial firm in university education as a part of their innovation collaboration with universities, this study presents a comparative, qualitative multiple case study of nine long-term university-industry relationships in Finland (Table 1). The cases were selected purposively following the concept of information-rich cases (Patton, 1990). Thus, all nine cases represented a close and long-term collaboration between a university research group (typically led by a professor or assistant professor) and an industrial firm's R\&D function. All the cases also included educational collaboration that has directly contributed to the rela- 


\section{Educational Involvement in Innovative University-Industry Collaboration}

\section{Leena Kunttu}

Table 1. Case study descriptions for the studied relationships between universities and industrial partners

\begin{tabular}{|c|c|c|c|c|c|c|}
\hline & Industrial Area & $\begin{array}{l}\text { Relationship } \\
\text { Age }\end{array}$ & $\begin{array}{l}\text { Joint R\&D } \\
\text { Project Area }\end{array}$ & $\begin{array}{l}\text { Forms of Educational } \\
\text { Collaboration }\end{array}$ & $\begin{array}{l}\text { Industry } \\
\text { Participants }\end{array}$ & $\begin{array}{l}\text { University } \\
\text { Participants }\end{array}$ \\
\hline Case A & $\begin{array}{l}\text { Electronic and } \\
\text { electrical } \\
\text { systems }\end{array}$ & 4 years & $\begin{array}{l}\text { Process } \\
\text { development } \\
\text { for R\&D } \\
\text { function }\end{array}$ & Student projects & R\&D Director & $\begin{array}{l}\text { Leader of the } \\
\text { research group }\end{array}$ \\
\hline Case B & Mobile devices & 5 years & $\begin{array}{l}\text { Software and } \\
\text { algorithm } \\
\text { development }\end{array}$ & $\begin{array}{l}\text { Student projects, } \\
\text { Thesis projects, } \\
\text { Jointly organized } \\
\text { courses }\end{array}$ & $\begin{array}{l}\text { Research } \\
\text { Manager }\end{array}$ & $\begin{array}{l}\text { Leader of the } \\
\text { research group }\end{array}$ \\
\hline Case C & $\begin{array}{l}\text { Software } \\
\text { products }\end{array}$ & 4 years & $\begin{array}{l}\text { Software and } \\
\text { algorithm } \\
\text { development }\end{array}$ & $\begin{array}{l}\text { Student projects, } \\
\text { Thesis projects }\end{array}$ & $\begin{array}{l}\text { Project } \\
\text { Manager }\end{array}$ & $\begin{array}{l}\text { Leader of the } \\
\text { research group }\end{array}$ \\
\hline Case D & $\begin{array}{l}\text { Software for } \\
\text { mobile devices }\end{array}$ & 5 years & $\begin{array}{l}\text { Algorithm } \\
\text { development }\end{array}$ & $\begin{array}{l}\text { Tailored degree } \\
\text { courses, Thesis } \\
\text { projects, Jointly } \\
\text { organized courses }\end{array}$ & $\begin{array}{l}\text { Technology } \\
\text { Manager }\end{array}$ & $\begin{array}{l}\text { Leader of the } \\
\text { research group }\end{array}$ \\
\hline Case E & $\begin{array}{l}\text { Hardware } \\
\text { platforms and } \\
\text { embedded } \\
\text { software }\end{array}$ & 5 years & $\begin{array}{l}\text { Software } \\
\text { development }\end{array}$ & $\begin{array}{l}\text { Student projects, } \\
\text { Thesis projects }\end{array}$ & R\&D Manager & $\begin{array}{l}\text { Leader of the } \\
\text { research group }\end{array}$ \\
\hline Case F & $\begin{array}{l}\text { Power } \\
\text { electronics } \\
\text { products }\end{array}$ & 13 years & $\begin{array}{l}\text { Hardware and } \\
\text { related } \\
\text { embedded } \\
\text { software } \\
\text { development }\end{array}$ & $\begin{array}{l}\text { Tailored degree } \\
\text { courses, Thesis } \\
\text { projects }\end{array}$ & $\begin{array}{l}\text { Senior } \\
\text { Director, } \\
\text { Global } \\
\text { Innovation }\end{array}$ & $\begin{array}{l}\text { Leader of the } \\
\text { research group }\end{array}$ \\
\hline Case G & Telecoms & 3 years & $\begin{array}{l}\text { Service product } \\
\text { development }\end{array}$ & $\begin{array}{l}\text { Student projects, } \\
\text { Thesis projects }\end{array}$ & $\begin{array}{l}\text { Development } \\
\text { Director }\end{array}$ & $\begin{array}{l}\text { Leader of the } \\
\text { research group }\end{array}$ \\
\hline Case H & $\begin{array}{l}\text { Engines and } \\
\text { power plants }\end{array}$ & 5 years & $\begin{array}{l}\text { Service product } \\
\text { development }\end{array}$ & $\begin{array}{l}\text { Student projects, } \\
\text { Thesis projects }\end{array}$ & $\begin{array}{l}\text { Business } \\
\text { Development } \\
\text { Director }\end{array}$ & $\begin{array}{l}\text { Leader of the } \\
\text { research group }\end{array}$ \\
\hline Case I & Heating systems & 6 years & $\begin{array}{l}\text { Service product } \\
\text { development }\end{array}$ & Student projects & R\&D Director & $\begin{array}{l}\text { Leader of the } \\
\text { research group }\end{array}$ \\
\hline
\end{tabular}




\section{Educational Involvement in Innovative University-Industry Collaboration}

\section{Leena Kunttu}

tional learning outcomes and innovation capabilities developed in the relationships. In most of the university-industry relationships studied, the collaboration had started as a research collaboration and the educational aspects evolved gradually over the years of collaboration. The data was collected on each case by means of recorded and transcribed interviews and the analysis of secondary materials, such as websites, company reports, and teaching materials. Each of the case interviews involved an interviewee on both sides of each case relationship, and all the interviewees were the key contributors to the relationship who also had directly participated in the educational aspects throughout the collaboration. To maintain confidentiality of the interview data, the interviewees are identified only by position (university=UNIV; industry=IND). The structure of the interviews were divided into three parts following the three phases of relational learning: 1) knowledge sharing, 2) joint sensemaking, and 3) knowledge integration. The interview data revealed that the educational collaboration in the selected university-industry relationships included the following four forms of educational collaboration:

1. Student projects for groups of undergraduate students. The projects were usually organized by universities as a part of their curriculum. The topics of the projects were initiated by the research project on university-industry relationships, and they were jointly supervised by industrial and university staff.

2. Thesis projects. Thesis projects were typically related to Master's or $\mathrm{PhD}$ theses. In this case, relevant thesis topics were also usually initiated by the research project, and they were co-supervised by university professors and industrial managers.

3. Tailored degree courses. The courses were organized by the university in cases where the industrial partner needed certain types of unique skills; that partner would then often provide employment opportunities for students who had passed these courses. The industrial partner's own R\&D staff also frequently taught and studied on these courses.

4. Jointly organized courses. These courses were organized jointly by the university and the industrial partner around the central topics related to the project on university-industry relationships. The teaching was organized jointly by university researchers and industrial $R \& D$ staff. The audience for the course was typically undergraduate or postgraduate students from the university, as well as industrial R\&D staff.

\section{Results}

This section presents an analysis of the interview data collected from each case in terms of knowledge sharing, joint sensemaking, and knowledge integration. At the end of this section, Table 2 summarizes the key findings.

\section{Knowledge sharing}

Transferring knowledge is one the primary drivers of innovation in inter-organizational collaboration (Tsai, 2001) in which both partners have to share their own previous knowledge and information that can often be tacit or experimental in nature. However, information sharing between partners requires an open and trusted atmosphere, particularly given that the information owned by the industrial actor in the relationship has both economic value and potential competitive advantage (Santoro \& Saparito, 2003). Therefore, the knowledge sharing and transfer in university-industry relationships requires engagement and commitment to the collaboration from both parties (Ankrah et al., 2013). The interview data showed that efficient knowledge transfer in the educational collaboration was based on long-term and close collaboration and personlevel relationships between industrial actors and universities:

"Our research collaboration started some years ago,
and it has been gradually extended as good results
have been achieved, and people from both sides
have become more familiar to each other. We star-
ted to participate to the educational activities quite
recently, since we felt that it could support our re-
search collaboration." (IND G)

"I feel that long-term personal relationships between the industrial partner's R\&D staff and our researchers represent one of the most critical facilitators of close collaboration and open communication in this relationship." (UNIV D)

The interview data also revealed that perhaps the most important form of educational knowledge transfer in the cases studied is different kinds of thesis projects:

"In our joint research projects, thesis projects were carried out from the beginning, but other forms of educational collaboration started after the collaboration had been ongoing for quite some time." (IND B) 


\section{Educational Involvement in Innovative University-Industry Collaboration}

\section{Leena Kunttu}

"I try to find competent students to who will base their theses (at both Master's and PhD levels) within the industrial projects around practical themes that really benefit our industrial partner. This way, the students become integrated into the industrial way of working, and many of them have also continued to work as employees of the industrial partner after graduation." (UNIV F)

The interview data also revealed that thesis projects can only be successful when the student writing the thesis is able to obtain relevant and good-quality supervision from both sides of the relationship. Here, again, the role of a trustful and close collaboration between universities and industry is emphasized (Santoro \& Saparito, 2003):

"Joint supervision also involves a great deal of direct interaction between us and the industrial partner, which can also generate new ideas and valuable knowledge transfer outside of the thesis project." (UNIV D)

"Many times, a thesis project has paved the way to a wider joint research project between us and our industrial partner." (IND E)

"Based on my experience, even a competent Master's student with a relevant background needs supervision from both university professors and the industrial partner to reach a successful outcome in their thesis project." (IND F)

The interview data in cases $\mathrm{B}$ and $\mathrm{D}$ also emphasizes the meaning of jointly organized courses in knowledge transfer between parties. The idea behind this kind of joint education is to involve both university staff and industrial $R \& D$ specialists both as lecturers and participants in the course, and in this manner provide both parties education on a new and important topic. Based on the interviews, these kinds of courses seem to be an effective way of gaining knowledge and skills in a new research area on both sides of the relationship:

"We have jointly organized courses with academia on central topics of our $R \& D$. The idea is to invite lecturers from both our organization and from our university partner to give lectures on the topic, which we then discuss together. The audience of the courses includes our $R \& D$ staff and university researchers and students. Personally, I feel that this kind of joint working is a really effective way of gaining knowledge on the area in question, and it definitely benefits both parties." (IND B)

\begin{abstract}
"Feedback from students and researchers regarding these courses has been outstanding." (UNIV B)

"The joint courses provide us as researchers, and also our students, with an excellent opportunity to apply our knowledge in a practical industrial context, to learn practical viewpoints and also to initiate new research directions together with industry." (UNIV D)
\end{abstract}

The interview data in cases B and D also shows that the joint educational activities have improved the knowledge transfer, interaction, and communication between the partners also outside the course activities. This is because the courses usually involve new people in the collaboration from both sides and help them to connect. This, in turn, often facilitates the development of new ideas and initiatives for further research directions:

"Several kinds of excellent ideas have been born during the discussions at these courses." (IND D)

\section{Joint sensemaking}

The development of new knowledge, ideas, and innovations in the collaborative relationship takes place in the process of joint sensemaking (Selnes \& Sallis 2003). In this process, the academic and industrial partners jointly work on development tasks in order to solve technical problems and other tasks related to their mutual development projects (Bäck \& Kohtamäki, 2016). In this effort, the partners can bring their own skills, knowledge, and earlier experience to the collaborative process and jointly create new, experimental knowledge. In the context of educational involvement, different kinds of student projects represent a central form of joint sensemaking between universities and industry. The purpose of the student projects is to involve university students in building a project around subjects provided by industry so that they can utilize their studies and apply the studied content in practice. The interview data confirms that this kind of practical learning procedure can facilitate learning within the relationship and the joint development of innovations (Brown \& Duguid, 1991):

"I have been teaching and supervising the student groups undertaking these practical projects for several years. In my opinion, students are very motivated to work on these projects. The students are particularly eager to collect information and use their knowledge to solve problems provided by the industrial partner, especially when it also involves this work." (UNIV A) 


\section{Educational Involvement in Innovative University-Industry Collaboration}

\section{Leena Kunttu}

"The results of the development work in the student work were so beneficial to our own development work that we decided to continue this kind of collaboration with our university partner from year to year." (IND I)

Thus, the interview data emphasized the importance of student projects as a valuable research resource in the joint research projects. The industrial actors especially appreciated the student groups' ability and eagerness to provide the firms with new views, ideas, and insights on the novel areas that were not so familiar to the firms' internal development staff:

"For us, student projects provide new and fresh insights, views, and ideas to support our own development work. They also increase our knowledge in the areas dealt with by the project work topics." (IND H)

Another area that arose in the interviews was the student groups' ability to collect and analyze valuable field data on, for example, customer experience, trends, and behaviour:

"It was a surprise to us how much valuable customer information and how many development ideas the student groups can collect in these projects. During their joint discussions with us, we can develop these ideas together in a way that really contributes to our internal R\&D." (IND E)

"The student groups have provided us with a lot of very useful information that would have been difficult to collect by ourselves." (IND H)

However, the majority of the interviewees also recognized that the student project work can only be successful when is properly guided and supervised by both industrial and academic parties:

"The university student groups are really a good and valuable resource, especially if both we and the university research staff have enough time to supervise them in the right direction." (IND B)

"We have achieved good results from student projects, especially with tasks where the projects are designed around a practical problem that somehow fits into the competence profiles and background of the students. Naturally, we have to put in extra effort to guide this work, but in any case it is a great learning experience for all of us." (UNIV A)
Another educational aspect of the collaboration includes dedicated degree courses for university students. The motivation behind these courses is usually a practical need for certain specific and unique skills that the industrial partner is lacking. The partner university then organizes this kind of education for its students, who were typically near to graduation:

"We have tried to answer to our industrial partner's educational needs by providing our students with courses containing dedicated content. It was also quite common for the industrial partner's internal R\&D staff to attend these courses, either as audience members or as lecturers or supervisors." (UNIV F)

"Opportunities to participate and give input to the degree courses provided by the university have been important to our $R \& D$. This way, we have been able to recruit graduates with a certain important competences." (IND D)

In some cases, the industrial partner has also provided teaching materials or tools to support university education in the selected field:

"We have provided our internal software development and testing environment targeted for experimenting with different kinds of new ideas for the use of universities, so that students can test their own ideas as part of their courses in this field." (IND B)

"The materials provided by the industrial partner, as well as the experiences from our joint projects, are very valuable practical teaching materials." (UNIV D)

This collaboration on dedicated degree courses is also important in terms of knowledge transfer, because many of the students who passed these courses ended up becoming employees of the companies:

"During these years of university collaboration, we have employed a number of students in this field after their graduation." (IND F)

"A significant number of our previous students, on both Master's and Doctoral levels, now work as members of the industrial partner's R\&D staff." (UNIV F) 


\section{Educational Involvement in Innovative University-Industry Collaboration}

\section{Leena Kunttu}

\section{Knowledge integration}

The third part of the relational learning process (Selnes \& Sallis, 2003) is related to the knowledge integration and implementation. The knowledge integration in university-industry relationships may involve the industrial commercialization of jointly developed innovations or technological solutions, such as commercialized product, process or service innovations, prototypes or other practical outcomes of the joint development work (Perkmann et al., 2013). In the case interviews, the interviewees were asked about the practical outcomes of the educational collaboration:

"The students should be able to present and document their project outcomes in a way that our internal developers can utilize them." (IND E)

"I know that many university professors appreciate academic outcomes such as publications more than practical ones, but I feel that the industrial collaboration project is only successful when the results can really be utilized in industry." (UNIV A)

Thesis projects and student group projects are typical examples of educational outcomes that have practical value for industry. However, the interview data shows that the results can be utilized only when they are presented in a practical manner:

"From our point of view, the outcomes of the student projects should not be scientific reports, but instead well-documented and implemented demonstrations of the developed methods that are both easy to understand and to further develop within our organization." (IND A)

"A well-made Master's thesis project has been the starting point for many successful internal $R \& D$ projects." (IND F)

"Even if a Master's or doctoral thesis is the primary result of academic work, we encourage students contributing to the industrial projects to write their documentation in such a way that it also meets the industrial partner's needs." (UNIV F)

One effective way to integrate the results of educational involvement is to also employ the students in the industrial implementation process. Thus, in all of the university-industry relationships studied in this article, the industrial partners have employed the students who contributed to their projects after their graduation:

\begin{abstract}
"Many project or thesis workers have continued to work on their topic as part of our R\&D organization." (IND B)
\end{abstract}

"Several of our previous students who contributed to the industrial partner's research projects in some way have been employed by the company." (UNIV C)

\begin{abstract}
"Experience has shown that one of the most effective ways of integrating research-based knowledge to our industrial goals is to recruit the person who has studied the topic within a university research group." (IND D)
\end{abstract}

Thus, boundary spanning activities in the relationship between scientists and industry (Siegel et al., 2004) represent an important way of integrating the knowledge obtained in educational collaboration within university-industry relationships.

\section{Conclusion}

This study presented a qualitative analysis of nine cases of educational involvement in university-industry research collaboration. The main goal of the study was to analyze the mechanisms and practices that are related to the educational aspects of this collaboration. The empirical analysis presented in the article indicates that this collaboration provides a number of factors that may facilitate relational learning, collaborative practices, and the creation of new knowledge in university-industry relationships, as summarized in Table 2. First, when industrial firms are given the opportunity to employ university students in their research projects in parallel with university research staff, many kinds of practical benefits can be achieved. For instance, almost all of the industrial managers interviewed mentioned university student projects as a valuable channel for new ideas, insights to customer experience and behaviour, as well as being an efficient way of recruiting competent R\&D staff to companies. Particularly, the recruitment of graduates with specific competences obtained in the university research projects has proved to be a very efficient way of transferring academic knowledge to industry. Second, jointly organized educational activities, such as training courses targeted to both university students and company internals, are an efficient method of gaining internal skills for the company and absorbing new information from the academic world. In a similar manner, these activities provide universities with access to real-world industrial $\mathrm{R} \& \mathrm{D}$ work and 


\section{Educational Involvement in Innovative University-Industry Collaboration}

\section{Leena Kunttu}

Table 2. A summary of the main findings of this study on university-industry relationships

\begin{tabular}{|c|c|c|c|}
\hline & Knowledge Sharing & Joint Sensemaking & Knowledge Integration \\
\hline Student Projects & $\begin{array}{l}\text { - An effective method for } \\
\text { transferring practical } \\
\text { knowledge from research or the } \\
\text { field }\end{array}$ & $\begin{array}{l}\text { - Establish interaction between } \\
\text { the students and industrial } \\
\text { partner } \\
\text { - Joint efforts to solve practical } \\
\text { industrial problems } \\
\text { - Provide new insights and fresh } \\
\text { ideas "from the outside world" }\end{array}$ & $\begin{array}{l}\text { - Provide practical results } \\
\text { - Involvement in industrial } \\
\text { implementation }\end{array}$ \\
\hline Thesis Projects & $\begin{array}{l}\text { - An important way of } \\
\text { transferring practical academic } \\
\text { knowledge } \\
\text { - Joint supervision of theses } \\
\text { facilitates university-industry } \\
\text { collaboration and interaction }\end{array}$ & $\begin{array}{l}\text { - Open new development areas } \\
\text { - Deepen university-industry } \\
\text { collaboration } \\
\text { - Provide industrial partner with } \\
\text { easy opportunities to } \\
\text { collaboration with research } \\
\text { groups }\end{array}$ & $\begin{array}{l}\text { - Clear documentation facilitates } \\
\text { industrial utilization } \\
\text { - Employing the graduate is an } \\
\text { easy way of integrating the } \\
\text { knowledge into industry }\end{array}$ \\
\hline $\begin{array}{l}\text { Tailored Degree } \\
\text { Courses }\end{array}$ & $\begin{array}{l}\text { - Are able to facilitate gaining } \\
\text { new academic competences } \\
\text { and resources that can be } \\
\text { accessed by industry }\end{array}$ & $\begin{array}{l}\text { - Joint working and discussions } \\
\text { in the courses facilitate joint } \\
\text { knowledge creation and deepen } \\
\text { research-based collaboration }\end{array}$ & $\begin{array}{l}\text { - Integrating the new } \\
\text { competences through } \\
\text { recruitments }\end{array}$ \\
\hline $\begin{array}{l}\text { Jointly } \\
\text { Organized } \\
\text { Courses }\end{array}$ & $\begin{array}{l}\text { - Represent an effective way of } \\
\text { gaining knowledge and } \\
\text { competences in a new research } \\
\text { area (on both sides of the } \\
\text { collaboration) }\end{array}$ & $\begin{array}{l}\text { - Joint working and discussions } \\
\text { in the courses facilitate joint } \\
\text { knowledge creation and deepen } \\
\text { research-based collaboration }\end{array}$ & $\begin{array}{l}\text { - Implementing the most } \\
\text { promising ideas developed in } \\
\text { the coursework }\end{array}$ \\
\hline
\end{tabular}

the challenges that come with it. Third, the interview data revealed that all educational activities involving industrial partners facilitate research-based information transfer from academia to industry, and they help industrial partners to efficiently utilize this information. This transfer is particularly important when the industrial partner needs to improve its skills in new, knowledge-intensive areas. Fourth, educational collaboration deepens research-based collaboration between academia and industry, which helps both sides to develop similar attitudes and arrive at a mutual understanding regarding the research process and collaborative practices.

The findings of the study are also of managerial interest given that most high-technology companies utilize collaborative university partnerships for their innovation and product development work, and thus face the challenge of utilizing the results achieved in this collaboration. This study presents a variety of collaborative practices that include educational involvement and that have a positive impact on these research collaborations, especially in terms of relational learning, knowledge creation, and commitment to the collaboration.

\section{Acknowledgements}

This article was developed from a paper presented at the ISPIM Innovation Conference in Vienna, Austria, June 18-21, 2017. ISPIM (ispim-innovation.com) - the International Society for Professional Innovation Management - is a network of researchers, industrialists, consultants, and public bodies who share an interest in innovation management. 


\section{Educational Involvement in Innovative University-Industry Collaboration}

\section{Leena Kunttu}

\section{About the Author}

Leena Kunttu is an innovation researcher at the University of Vaasa in Finland. She received her $\mathrm{PhD}$ degree in Information Technology from the Tampere University of Technology, Finland, in 2006. From 2007 to 2012, she served as Senior Manager in an area of innovation at the Nokia Corporation. During her career in Nokia, she led a number of collaborative projects between the company and external research institutes, such as universities. She also led and participated in projects that collected and analyzed field data from end users and customers to provide inputs for R\&D. Since 2015, Dr. Kunttu has served as a researcher in the area of innovation at the University of Vaasa, while also carrying out $\mathrm{PhD}$ studies in industrial innovation. Her current research interests include university-industry collaboration, educational involvement, and the commercialization of university technologies.

\section{References}

Ankrah, S., \& Al-Tabbaa, O. 2015. Universities-Industry Collaboration: A Systematic Review. Scandinavian Journal of Management, 31(3): 387-408.

http://doi.org/10.1016/j.scaman.2015.02.003

Ankrah, S. N., Burgess, T. F., Grimshaw, P., \& Shaw, N. E. 2013. Asking Both University and Industry Actors about Their Engagement in Knowledge Transfer: What Single-Group Studies of Motives Omit. Technovation, 33(2-3): 50-65.

http://doi.org/10.1016/j.technovation.2012.11.001

Arvanitis, S., Kubli, U., \& Woerter, M. 2008. University-Industry Knowledge and Technology Transfer in Switzerland: What University Scientists Think about Co-Operation with Private Enterprises. Research Policy, 37(10): 1865-1883. http://doi.org/10.1016/j.respol.2008.07.005

Bäck, I., \& Kohtamäki, M. 2016. Joint Learning in Innovative R\&D Collaboration. Industry and Innovation, 23(1): 62-86. http://doi.org/10.1080/13662716.2015.1123613

Brown, J. S., \& Duguid, P. 1991. Organizational Learning and Communities-of-Practice: Toward a Unified View of Working, Learning, and Innovation. Organization Science, 2(1): 40-58. https://doi.org/10.1287/orsc.2.1.40

Bruneel, J., D’Este, P., \& Salter, A. 2010. Investigating the Factors that Diminish the Barriers to University-Industry Collaboration. Research Policy, 39(7): 858-868. http://doi.org/10.1016/j.respol.2010.03.006

D'Este, P., \& Patel, P. 2007. University-Industry Linkages in the UK: What Are the Factors Underlying the Variety of Interactions with Industry? Research Policy, 36(9): 1295-1313. http://doi.org/10.1016/j.respol.2007.05.002
Kuwada, K. 1998. Strategic Learning: The Continuous Side of Discontinuous Strategic Change. Organization Science, 9(6): 719-736.

https://doi.org/10.1287/orsc.9.6.719

Laursen, K., \& Salter, A. 2004. Searching High and Low: What Types of Firms Use Universities as a Source of Innovation? Research Policy, 33(8): 1201-1215.

http://doi.org/10.1016/j.respol.2004.07.004

Maietta, O. W. 2015. Determinants of University-Firm R\&D Collaboration and Its Impact on Innovation: A Perspective from a Low-Tech Industry. Research Policy, 44: 1341-1359. http://doi.org/10.1016/j.respol.2015.03.006

Patton, M. Q. 1990. Qualitative Evaluation and Research Methods. London: Sage Publications.

Perkmann, M., Tartari, V., McKelvey, M., Autio, E., Broström, A., D’Este, P., Fini, R., Geuna, R., Hughes, A., Krabel, S., Kitson, M., Llerena, P., Lissoni, F., Salter, A., \& Sobrero, M. 2013. Academic Engagement and Commercialisation: A Review of the Literature on University-Industry Relations. Research Policy, 42(2): 423-442. http://doi.org/10.1016/j.respol.2012.09.007

Santoro, M. D., \& Chakrabarti, A. K. 1999. Building Industry-University Research Centers: Some Strategic Considerations. International Journal of Management Reviews, 1(3): 225-244. http://doi.org/10.1111/1468-2370.00014

Santoro, M. D., \& Saparito, P. 2003. The Firm's Trust in Its University Partner as a Key Mediator in Advancing Knowledge and New Technologies. IEEE Transactions on Engineering Management, 50(3): 362-373.

https://doi.org/10.1109/TEM.2003.817287

Selnes, F., \& Sallis, J. 2003. Promoting Relationship Learning. Journal of Marketing, 67(3): 80-95.

https://doi.org/10.1509/jmkg.67.3.80.18656

Siegel, D. S., Waldman, D. A., Atwater, L. E., \& Link, A. N. 2004. Toward a Model of the Effective Transfer of Scientific Knowledge from Academicians to Practitioners: Qualitative Evidence from the Commercialization of University Technologies. Journal of Engineering and Technology Management, 21(1-2): 115-142. http://doi.org/10.1016/j.jengtecman.2003.12.006

Tsai, W. 2001. Knowledge Transfer in Intraorganizational Networks: Effects of Network Position and Absorptive Capacity on Business Unit Innovation and Performance. Academy of Management Journal, 44(5): 996-1004. http://doi.org/10.2307/3069443

Weckowska, D. M. 2015. Learning in University Technology Transfer Offices: Transactions-Focused and Relations-Focused Approaches to Commercialization of Academic Research. Technovation, 41-42: 62-74.

http://doi.org/10.1016/j.technovation.2014.11.003

Citation: Kunttu, L. 2017. Educational Involvement in Innovative University-Industry Collaboration. Technology Innovation Management Review, 7(12): 14-22. http://doi.org/10.22215/timreview/1124

Keywords: university-industry collaboration, academic involvement, educational involvement, innovation, knowledge transfer 


\section{Academic Affiliations and Funding Acknowledgements}

Canadà
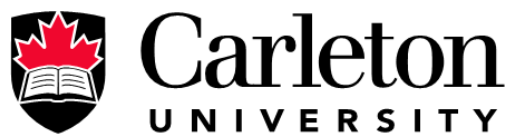

U N I V E R S I T Y

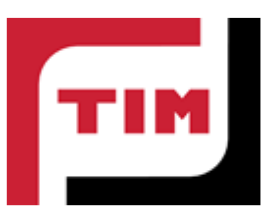

The Federal Economic Development Agency for Southern Ontario (FedDev Ontario; feddevontario.gc.ca) is part of the Innovation, Science and Economic Development portfolio and one of six regional development agencies, each of which helps to address key economic challenges by providing regionallytailored programs, services, knowledge and expertise.

- The TIM Review receives partial funding from FedDev Ontario's Investing in Regional Diversification initiative.

Technology Innovation Management (TIM; timprogram.ca) is an international master's level program at Carleton University in Ottawa, Canada. It leads to a Master of Applied Science (M.A.Sc.) degree, a Master of Engineering (M.Eng.) degree, or a Master of Entrepreneurship (M.Ent.) degree. The objective of this program is to train aspiring entrepreneurs on creating wealth at the early stages of company or opportunity lifecycles.

- The TIM Review is published in association with and receives partial funding from the TIM program. 